\title{
Dilation of ascending aorta in Turner syndrome - short-term follow-up
}

\author{
Kristian H Mortensen*1, Britta E Hjerrild1, Niels H Andersen², \\ Keld E Sorensen ${ }^{2}$, Arne Hoerlyck ${ }^{3}$, Erik Lundorf ${ }^{4}$, Jens S Christiansen ${ }^{1}$ and \\ Claus H Gravholt ${ }^{1}$
}

Address: ${ }^{1}$ Medical Department M (Endocrinology and Diabetes) and Research Laboratories, Aarhus Hospital NBG, Aarhus University Hospital, Aarhus, Denmark, ${ }^{2}$ Department of Cardiology, Skejby Hospital, Aarhus University Hospital., Aarhus, Denmark, ${ }^{3}$ The MR Centre, Skejby Hospital, Aarhus University Hospital, Aarhus, Denmark and ${ }^{4}$ Department of Radiology, Skejby Hospital, Aarhus University Hospital, Aarhus, Denmark

* Corresponding author

from 13th Annual SCMR Scientific Sessions

Phoenix, AZ, USA. 21 -24 January 2010

Published: 21 January 2010

Journal of Cardiovascular Magnetic Resonance 20 I0, I2(Suppl I):O27 doi:I0.1 I86/I532-429X-I2-SI-O27

This abstract is available from: http://jcmr-online.com/content/I2/SI/O27

(C) 2010 Mortensen et al; licensee BioMed Central Ltd.

\section{Background}

Aortic dissection causes excess mortality in Turner syndrome. Cross-sectional studies show increased prevalence of aortic dilatation, the principal surrogate risk marker for the aortic event. Increased risk has been linked with congenital cardiovascular abnormalities, karyotype, and blood pressure

\section{Purpose}

To study the previously uninvestigated natural cause of the aortopathy in Turner syndrome over time, and possible predictors of increasing aortic size

\section{Methods}

Prospective follow-up study comparing Turner syndrome ( $\mathrm{N}=102$, examined twice) with healthy age-matched female controls ( $N=65$, examined once). Non-contrast, respiratory-navigated, ECG-gated, 3D SSFP MRI analyzed for thoracic aortic dimensions at eight positions. BlandAltman reproducibility testing determined the limits of agreement. Echocardiography assessed aortic valve morphology. Ambulatory blood pressures were performed

\section{Results}

Of 102 women enrolled at baseline, 11 were lost to follow-up, and 80 had technically successful magnetic resonance imaging scans at both baseline and follow-up.
Aortic diameters were comparable in Turner syndrome (baseline) and controls, except from the distal aortic arch and the aortic isthmus (classical site of coarctation) (Table 1 ). The prevalence of aortic dilation was significantly higher in Turner syndrome both before and after indexing for body surface area. In Turner syndrome, bicuspid aortic valve, aortic coarctation, and elongated transverse aortic arch were present in $28 \%, 11 \%$, and $38 \%$. 45, x karyotype was seen in $61 \%$. Blood pressures and heart rates were significantly elevated in Turner syndrome; $23 \%$ took antihypertensive medication. The mean follow-up time was 2.4 \pm 0.4 years (range: 1.4 to 3.5 years). The sinutubular $(\mathrm{P}=$ $0.02)$ and mid-ascending $(P=0.009)$ aortic diameters increased with dilatation rates of 0.16 and $0.23 \mathrm{~mm} / \mathrm{year}$, respectively. The remaining thorax aortic diameters showed no statistically significant changes. None of the currently identified factors of risk for aortic dilatation or dissection predicted the increase. Overall, twenty-two of $80(30 \%)$ Turner syndrome patients had an aortic diameter increment above the limits of agreement, ranging from 0.7 to $2.7 \mathrm{~mm}$ /year (highest for the mid-ascending aorta). No congenital anomaly or karyotype was more prevalent in this group, where daytime and 24-hour heart rates, but not blood pressure, were significantly higher $(\mathrm{P}<0.03)$. Antihypertensive treatment did not predict reduced increases in aortic diameter over time 
Table I: Maximum aortic diameter $(\mathrm{mm})$ in Turner syndrome at inclusion and after an average follow-up time of 2.4 years compared with age-matched healthy controls (examined once).

\begin{tabular}{|c|c|c|c|c|c|c|}
\hline & \multicolumn{3}{|c|}{$\begin{array}{l}\text { Turner syndrome } \\
(N=80)\end{array}$} & \multirow{2}{*}{$\begin{array}{l}\text { Pf } \\
\text { (Turner syndrome at } \\
\text { baseline versus follow-up) }\end{array}$} & \multirow[t]{2}{*}{$\begin{array}{l}\text { Controls } \\
(N=65)\end{array}$} & \multirow{2}{*}{$\begin{array}{l}P \ddagger \\
\text { (Controls versus Turner } \\
\text { syndrome at baseline) }\end{array}$} \\
\hline & Baseline & Follow-up & $\begin{array}{l}\text { Change during } \\
\text { follow-up }\end{array}$ & & & \\
\hline $\begin{array}{l}\text { Sinotubular } \\
\text { junction }\end{array}$ & $25.3 \pm 4.3$ & $25.7 \pm 4.0$ & $0.4(0.1 ; 0.7)$ & 0.02 & $25.6 \pm 2.7$ & 0.7 \\
\hline Ascending aorta & $27.5 \pm 5.0$ & $28.0 \pm 5.1$ & $0.6(0.2 ; 0.9)$ & 0.009 & $26.5 \pm 3.4$ & 0.2 \\
\hline $\begin{array}{l}\text { Distal ascending } \\
\text { aorta }\end{array}$ & $25.3 \pm 3.6$ & $25.2 \pm 3.6$ & $-0.1(-0.3 ; 0.2)$ & 0.8 & $25.3 \pm 2.9$ & 0.9 \\
\hline $\begin{array}{l}\text { Proximal aortic } \\
\text { arch }\end{array}$ & $23.4 \pm 3.6$ & $23.4 \pm 3.4$ & $0.1(-0.1 ; 0.4)$ & 0.4 & $24.1 \pm 2.8$ & 0.2 \\
\hline Distal aortic arch & $20.5 \pm 2.7$ & $20.5 \pm 2.6$ & $0.1(-0.1 ; 0.3)$ & 0.5 & $22.8 \pm 2.4$ & $<0.0001$ \\
\hline Aortic isthmus & $19.3 \pm 2.3$ & $19.4 \pm 2.3$ & $0.1(-0.1 ; 0.3)$ & 0.3 & $21.4 \pm 2.3$ & $<0.0001$ \\
\hline Descending aorta & $19.5 \pm 2.8$ & $19.4 \pm 2.7$ & $-0.05(-0.2 ; 0.1)$ & 0.6 & $19.7 \pm 2.3$ & 0.7 \\
\hline $\begin{array}{l}\text { Distal descending } \\
\text { aorta }\end{array}$ & $18.2 \pm 2.2$ & $18.1 \pm 2.2$ & $-0.1(-0.2 ; 0.1)$ & 0.2 & $18.3 \pm 2.3$ & 0.7 \\
\hline
\end{tabular}

$t$ : Paired Student's t-test, equal variances assumed

‡: Independent Students t-test, equal variances assumed

\section{Conclusion}

An ascending aortopathy in adult Turner syndrome was indicated by a general increment of sinutubular and midascending aortic size. Furthermore, a seemingly accelerated dilatory aortopathy was evident in a third of the cohort where the previously indices of risk did not clearly predict the increase in aortic size.

Publish with Biomed Central and every scientist can read your work free of charge

"BioMed Central will be the most significant development for disseminating the results of biomedical research in our lifetime. "

Sir Paul Nurse, Cancer Research UK

Your research papers will be:

- available free of charge to the entire biomedical community

- peer reviewed and published immediately upon acceptance

- cited in PubMed and archived on PubMed Central

- yours - you keep the copyright
BioMedcentral 